\title{
Technological and methodical process integration in manufacturing of monoclonal antibodies
}

\author{
Petra Gronemeyer, Jochen Strube \\ From 24th European Society for Animal Cell Technology (ESACT) Meeting: C2P2: Cells, Culture, Patients, Products \\ Barcelona, Spain. 31 May - 3 June 2015
}

\begin{abstract}
Background
A steady increase of product titers and the corresponding change in impurity composition represent a challenge for development and optimization of antibody production processes $[1,2]$. Concentration and composition of impurities like host cell proteins (HCP) are critical for efficient process development. These impurities show significant variations, which primarily depend on cell culture conditions. They have a strong influence on the downstream processing (DSP) and costs [2]. It is already shown that not optimized changes of parameters in USP can change the impurity profile by a factor of 7 [3]. The resulting "bottleneck" in DSP requires new optimization, technology and development approaches. These include the optimization and adaptation of existing unit operations respective to the new separation task, the assessment of alternative separation technologies and the search for new methods in process development [2].
\end{abstract}

\section{Material and Methods}

By changing cell culture media compositions according to DoE screening designs, influences of media components on the HCP concentration and composition are identified. A media optimization is carried out regarding not only high product titers and cell growth but also $\mathrm{HCP}$ concentration and composition. By these experiments, different fermentation broths are produced containing different concentrations and compositions of HCP. These broths are used in subsequent development of ATPE and precipitation. A DoE based screening is carried out to identify the influence of following parameters: system composition, $\mathrm{NaCl}$, cell number, viability,

\footnotetext{
* Correspondence: gronemeyer@itv.tu-clausthal.de Institute for Separation and Process Technology, Clausthal University of Technology, 38678 Clausthal-Zellerfeld, Germany
}

$\mathrm{pH}$, product concentration, precipitant concentration, temperature, precipitation environment.

\section{Results}

ATPE can be used as cell harvest method. It separates more than $95 \%$ of cells from the broth. Almost $100 \%$ of the antibody can be transferred in the top phase. The product is concentrated within the target phase at reduced volumes. At the same time, a first purification step is carried out removing HCP, DNA and media components. A subsequent precipitation removes the majority of remaining $\mathrm{HCP}$ and other impurities. The integration of ATP and precipitation can result into a significant reduction of costs and efforts. An optimization of the overall manufacturing process can be advanced by regarding process depending impurities resulting from the fermentation process. The optimization of USP towards relatively high product titers as well as an impurity spectrum which is easy to separate from the product can improve the manufacturing process concerning the total process costs.

\section{Conclusions}

A combination of an integration of upstream and downstream processing regarding process depending impurities as well as an establishment and integration of alternative separation mechanisms can present an interesting solution to purify high concentrated antibodies.

Published: 14 December 2015

\section{References}

1. Jain $E$, Kumar $A$ : Upstream processes in antibody production: Evaluation of critical parameters. BiotechnolAdv 2008, 26:46-72.

2. Gronemeyer P, Ditz R, Strube J: Trends in Upstream and Downstream Process Development for Antibody Manufacturing. Bioeng 2014, 1:188-212.

3. Szapiel N, Zhang J, Hickey J, Ghose S: Profiling of host cell proteins by two-dimensional difference gel electrophoresis (2D-DIGE): Implications 
for downstream process development. Biotechnol Bioeng 2010, , 105:

306-316.

doi:10.1186/1753-6561-9-S9-P39

Cite this article as: Gronemeyer and Strube: Technological and

methodical process integration in manufacturing of monoclonal antibodies. BMC Proceedings 2015 9(Suppl 9):P39.

Submit your next manuscript to BioMed Central and take full advantage of:

- Convenient online submission

- Thorough peer review

- No space constraints or color figure charges

- Immediate publication on acceptance

- Inclusion in PubMed, CAS, Scopus and Google Scholar

- Research which is freely available for redistribution

Submit your manuscript at 